
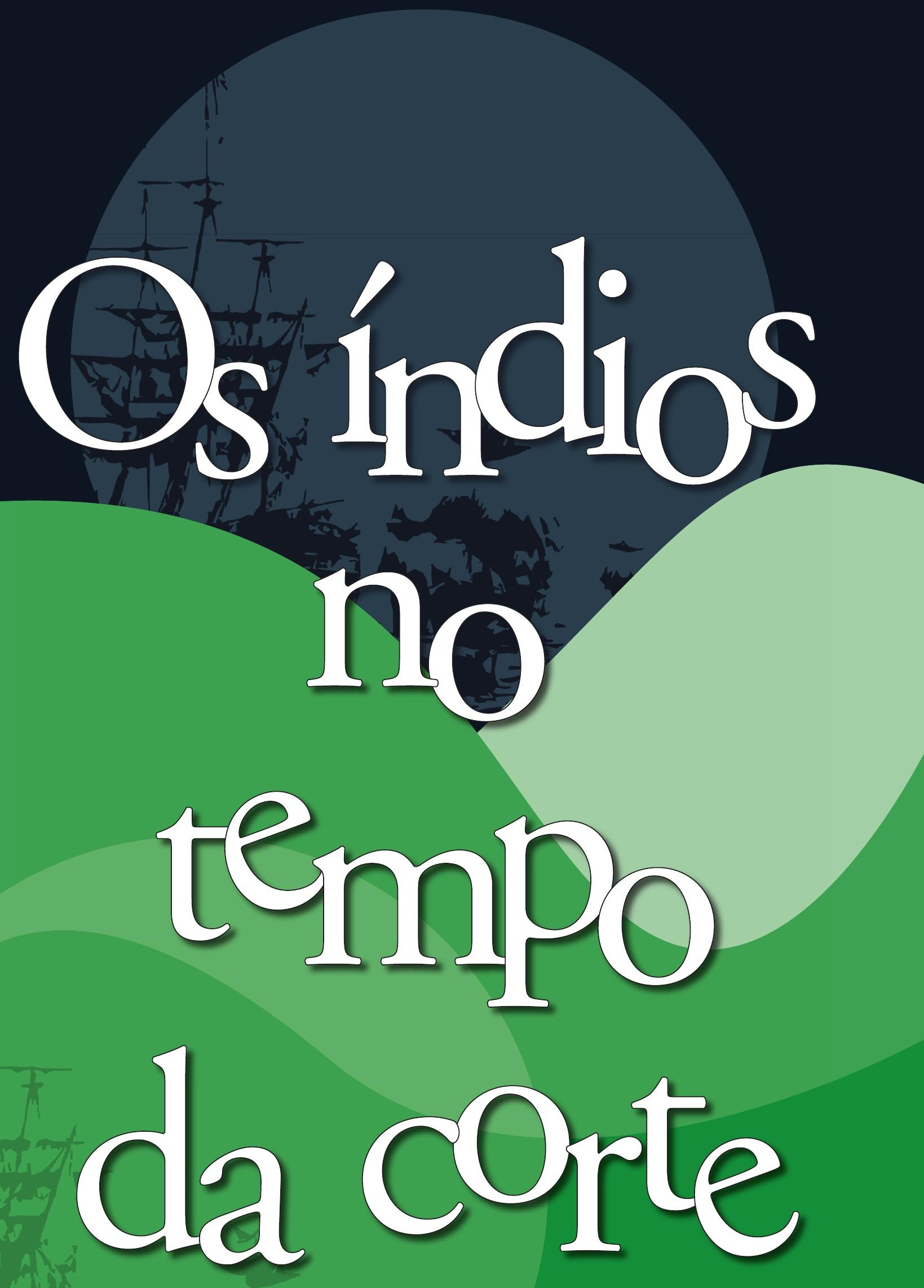


\section{Reflexões sobre política indigenista e cultura política indígena no Rio de Janeiro oitocentista}

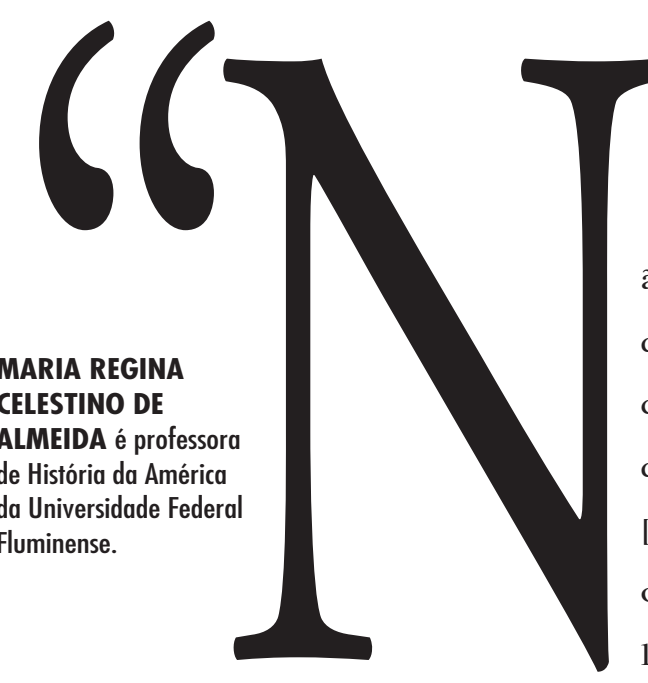

MARIA REGINA CELESTINO DE ALMEIDA

ão é conforme aos meus princípios religiosos e políticos o querer estabelecer minha autoridade [...] por meio de mortandades e crueldades contra os índios, extirpando as suas raças, que antes desejo adiantar, por meio da religião e civilização, [...] e que só desejo usar da força com aqueles que ofendem os meus vassalos, e que resistem aos brandos meios de civilização que lhes mando oferecer" ${ }^{\text {. }}$

Declaração de 10/4/1809, apud Manuela Carneiro da Cunha, "Política Indigenista no Século XIX", in Manuela Carneiro da Cunha (coord.) História dos Indios no Brasil. São Paulo, Companhia das Letras, 1992, p. 152.

2 "Carta Régia ao Governadore Capitão General da Capitania de Minas Gerais sobre a Guerra aos Índios Botocudos. 13/05/1808", in Manuela Carneiro da Cunha, Legislação Indigenista no Século XIX-Üma Compilação (1808-1809), São Paulo, Edusp, 1992, pp. 57-61.

3 A escravização dos índios através da guerra justa manteve-se, com raras exceções, durante todo o período colonial atéser proibida pela legislação pombalina, porém, na prática, continuov ocorrendo em várias regiões, sobretudo nos sertões de Minas Gerais. Sobre isso ver: Hal Langfur, "Uncertain Refuge Frontier Formation and the Origin of the Botocudo War in Late Colonial Brazil", in Hispanic American Historical Review, 82:2, 2002, pp 215-56. Sobre a política ind genista do período colonial ver: Beatriz Perrone-Moisés "Índios Livres e Índios Escravos",
Essa declaração do príncipe regente, justificando a guerra decretada contra os botocudos, em maio de $1808^{2}$, e estendida, pouco depois, aos caingangues, aos quais especificamente se refere, evidencia a ambivalência da política indigenista da Coroa portuguesa e a impossibilidade de se generalizar os efeitos da chegada da corte no Brasil sobre os povos indígenas. Se o príncipe regente decretou guerra contra alguns índios, procurou beneficiar outros. Nesse sentido, sua política não diferia muito da que vinha sendo praticada desde o início da colonização ${ }^{3}$.

As diferenças regionais, incluindo diversidades entre os níveis de inserção dos índios no mundo colonial e suas reações aos colonizadores, constituíram sempre sério empecilho ao estabelecimento e aplicação de leis gerais para o conjunto dos povos indígenas na América portuguesa. Do século XVI ao XIX, a política indigenista da Coroa, raras vezes, teve caráter geral e, quando isso ocorreu, adaptações foram inevitáveis para atender às condições regionais. 
in Manuela Carneiro da Cunha (coord.), História dos Índios no Brasil, op. cit, pp. 115-32; José Oscar Beozzo, Leise Regimentos das Missões: Política Indigenista no Brasil, São Paulo, Loyola, 1983

4 M. Regina Celestino de AFmeida, "Índios, Missionários e Políticos: Discursos e Atuacões Político-culturais no Rio de Janeiro Oitocentista", in Rachel Soihet, M. Fernanda Bicalho, M. de Fátima S. Gouvêa (coords.), Culturas Políticas - Ensaios de História Cultural História Política e Ensino de História, Rio de Janeiro, Mauad, 2005 , pp. 235-55

5 LuizR. Barros Mott, Piauí Colonial: População, Economia e Sociedade, Teresina, 1985, Projeto Petrônio Portela, p. 121, apud Beatriz G. Dantas, José Augusto L. Sampaio e Maria Rosario G. de Carvalho, "Os Povos Indígenas no Nordeste Brasileiro", in Manuela Carneiro da Cunha (coord.), História dos Indios no Brasil, op. cit., p. 451 .

6 Para um estudo detalhado sobre essa aldeia ver: Marcelo Lemos, O Índio Virou Pó de Café? - A Resistência dos Indios Coroados de Valença Frente à Expansão Cafeeira no Vale do Paraíba (1788-1836), dissertação de mestrado, Rio de Janeiro, UER, 2004

7 Decreto de 26 de março de 1819, in 1 . Norberto de Souza Silva, "Memória Histórica e Documentada das Aldeias de Indios do Rio de Janeiro", in Revista do Instituto Histórico e Geográfico do Brasil, Rio de aneiro, abril/junho de 1854 v. 62, pp. 538-9.

8 "Diretório que se Deve Observar nas Povoações dos Indios do Pará e Maranhão, enquanto Sua Majestade não Mandar o Contrário", in Rita Heloísa de Almeida, ODiretório dos Indios - UmProjeto de "Civilizaçãono Brasil do Século XVIII, Brasília, Editora Universidade de Brasília, 1997.

9 Sobre isso ver: M. Carneiro da Cunha, Legislação Indigenista, op. cit. Sobre a aplicação da política pombalina em diferentes regiões, ver: Ricardo Pinto de Medeiros, "Política Indigenista e seus Reflexos nas Capitanias do Norte da América Portuguesa", in Ricardo Pinto de Medeiros e Carla Mary S. Oliveira (coords.), Novos Olhares sobre as Capitanias do Norte do Estado do Brasil, João Pessoa, Editora Universitária UFPB, 2007, pp. 125-59; Elisa F. Garcia, As Diversas Formas de Ser Índio: Políticas Indígenas e Políticas Indigenistas no Extremo Sul da América Portuguesa, Rio de Janeiro, Arquivo Nacional
Para os índios aldeados, há séculos, em contato intenso com os colonizadores, a chegada da corte não acarretou mudanças muito acentuadas. Para eles, a política indigenista praticamente não se alterou, embora indiretamente tenham sido muito afetados pelo desenvolvimento maior da capitania, que acarretou o aumento de conflitos em torno de suas terras. Esses índios já tinham, há muitas gerações, incorporado uma cultura política que valorizava acordos e negociações com autoridades e com o próprio rei e mantinham-se nas aldeias reivindicando seus direitos conforme tinham feito nos períodos anteriores ${ }^{4}$. Para eles, a corte no Rio de Janeiro significava a possibilidade de reivindicar direitos diretamente ao rei que, por sua vez, os recebia com a devida atenção, cumprindo seu papel de monarca justiceiro, preocupado com obem-estar de seus súditos indígenas. Podiam vir de regiões distantes, como em 1811, quando "[...] o principal da aldeia de São Gonçalo, no Piauí, fora ao Rio de Janeiro apresentar pessoalmente sua queixa ao príncipe regente, que, depois de ouvi-lo, o deferiu benignamente, enchendoo de honras e presentes"5.

Situações diferenciadas entre grupos indígenas geravam, pois, procedimentos diversos. Tais situações podiam se apresentar em regiões muito próximas, como ocorreu no interior da capitania do Rio de Janeiro. Ao iniciar-se o século XIX, índios aldeados e índios considerados "bravos" compunham a diversidade das populações indígenas na capitania, tendo sido alvo e agentes de políticas indigenistas e indígenas, com estratégias diferenciadas. O objetivo deste trabalhoé refletir sobre essas políticas, procurando perceber possíveis influências da presença da corte sobre elas. Enfoca-se mais diretamente a aldeia de Valença ${ }^{6}$, criada, em 1801, com índios coroados que, na segunda década do Oitocentos, enfrentaram conflitos de terra resolvidos com uma provisão favorável de D. João VI ${ }^{7}$. Com base na legislação do período, na correspondência entre autoridades e em alguns requerimentos de índios e relatos de viajantes, é possível observar que a cultura política do Antigo Regime parece ter sido rapidamente assi- milada pelos novos aldeados. Suas alianças e atuações políticas assemelham-se, em parte, às de seus pares em aldeias mais antigas que, nessa mesma época, igualmente enfrentavam problemas por usurpação de terras e recorriam à justiça do rei.

\section{POLÍTICA INDIGENISTA E POLLITICA INDÍGENA NA CAPITANIA DO RIO DE JANEIRO: DE MEADOS DO SÉCULO XVIII AO TEMPO DA CORTE}

Ao iniciar-se o século XIX, a política indigenista da América portuguesa ainda se pautava, em grande parte, pelas diretrizes do Diretório dos Índios ${ }^{8}$, legislação estabelecida no âmbito das reformas pombalinas que visava a assimilar os índios ao Império português. Apesar de oficialmente extinto pela Carta Régia de 1798, o Diretório continuaria servindo de parâmetro oficial em várias regiões, com as necessárias adaptações, conforme as situações locais e as populações com as quais se lidava9. Em algumas regiões efetuavam-se descimentos e estabeleciam-se novas aldeias; em outras se desencadeavam guerras e, em áreas de colonização mais antiga, pregava-se o fim das aldeias, com o argumento de que os índios já estavam civilizados e misturados à massa da população. Essas práticas coexistiram e se sucederam de meados do século XVIII ao XIX, no qual a política indigenista manteve e acentuou o caráter assimilacionista lançado por Pombal ${ }^{10}$.

O papel essencial de garantir a soberania dos territórios no ultramar, atribuído aos índios desde os primórdios da colonização, seria particularmente acentuado na conjuntura aqui abordada, quando as coroas ibéricas concentravam esforços para demarcar suas fronteiras coloniais e os índios tinham aí um papel fundamental. Considerados pela própria documentação como "muralhas do sertão", eram disputados pelos monarcas por sua condição de 
súditos, tanto no norte, quanto no sul do continente ${ }^{11}$.

Terminado o século XVIII e extinto o Diretório, essas contendas se arrastariam pelas primeiras décadas do Oitocentos e, com elas, seriam mantidas as preocupações da Coroa em aliciar os índios como vassalos fiéis, que garantiriam sua soberania em territórios distantes. Elucidativa a esse respeito é a instrução encaminhada pelo príncipe regente ao governador-geral do Rio Grande, em 1807, um ano antes de deslocar-se para a colônia

“Recomendo a vossa consideração não só os índios das duas aldeias de São Lourenço e de Nossa Senhora dos Anjos, já formada naquele governo, mas a redução e união dos mais que puderem estabelecer-se, conservando-lhes as terras, já distribuídas, e dando-lhes as que demais carecerem, usando com eles dos meios de moderação e brandura [...]. Observareis o mesmo com as sete aldeias, ou missões espanholas, que se unirão ao mesmo Governo, enquanto nele permanecerem. E porque sou informado que o cacique Gaspar com o seu povo veio amparar-se, e dedicar-se ao meu serviço naquele governo, lhe prestareis toda a proteção e auxílio compatível com a sua fidelidade, e com o zelo que mostrar pelo mesmo serviço" ${ }^{12}$.

A instrução do príncipe revela o quanto a política indigenista da Coroa portuguesa apostava na aliança com os índios para assegurar suas fronteiras, bem como sua consciência sobre a necessidade de tratá-los bem e conceder-lhes terras. Revela também a continuidade da política do Diretório e as diversidades das situações dos índios e das aplicações da lei, pois refere-se aos aliados das aldeias de São Nicolau e Nossa Senhora dos Anjos, que já faziam parte do reino português e assim deviam ser conservados; e aos que deviam ser atraídos: os súditos do rei espanhol que poderiam aderir ao domínio luso; e os de vida errante nos sertões, como os charruas que, liderados pelo cacique Gaspar, mostravam-se interessados em tornar-se seus fiéis vassalos. A todos se recomendava tratamento brando, garantia de terras, auxílio e proteção para torná-los fiéis e zelosos no serviço ao monarca português. Esses índios responderam a essas políticas comestratégias diversas, barganhando com a rivalidade entre os soberanos ${ }^{13}$.

Longe das fronteiras externas, a política assimilacionista para os índios também se aplicava com procedimentos diversos. $\mathrm{Na}$ capitania do Rio de Janeiro, os inimigos eram os chamados "índios bravos" e estavam em fronteiras internas. Ali, no final do século XVIII e início do XIX, às margens do Rio Paraíba, tanto na região norte quanto na sul, isto é, nas atuais fronteiras com Minas Gerais e São Paulo, coroados e puris, entre outros, impunham obstáculos à ocupação da região conhecida, então, como "sertão dos índios bravos", e as autoridades envidavam esforços para atraí-los.

Nessas áreas, a política indigenista visava a reduzir os índios, estabelecendo aldeias que garantissem a soberania da região para a Coroa e dessem aos moradores segurança e acesso à mão-de-obra indígena, em moldes muito semelhantes aos empregados em séculos anteriores na criação das antigas aldeias ${ }^{14}$. Para essas, no entanto, a mesma política indigenista propunha a extinção. Habitadas por índios em intenso contato com a sociedade colonial por várias gerações e muito mais próximas ao núcleo da cidade, os problemas ali eram diversos. Nessas regiões, moradores e câmaras municipais interessavam-se mais pelas terras dos índios do que por seu trabalho, e os conflitos se acentuavam com o desenvolvimento da capitania. Ali, após a expulsão dos jesuítas, os índios permaneceram nas aldeias, conservando os direitos sobre terras e rendimentos coletivos, cada vez mais ameaçados pela nova política que incentivava a miscigenação e a presença de não-índios no interior das aldeias. Esses índios já agiam, porvárias gerações, de acordo com a cultura política do Antigo Regime e, em contrapartida aos discursos que os consideravam misturados à massa populacional, apresentavam petições por direitos que Sua Majestade lhes havia concedido por sua condição de súditos fiéis ao atendimento dos serviços do rei ${ }^{15}$. Para esses, a presença da corte significava, como (prelo): Ângela Domingues, Quando os Indios Eram Vas salos. Colonização e Relações de Poder no Norte do Brasil na Segunda Metade do Século XVIII, Lisboa, Comissão Nacional para as Comemorações dos Descobrimentos Portugueses, 2000

10 Sobre a política indigenista no século XIX, ver: M. Carneiro da Cunha, "Política Indigenista..." op. cit.

11 Sobre a Região Norte, onde eram chamados "muralhas do sertão", ver: Nadia Faraje, As Muralhas do Sertão: os Povos Indígenas no Rio Branco e a Colonização, Rio de Janeiro, Paz e Terra/Anpocs, 1991; Ângela Domingues, op. cit Sobre a Região Sul, ver: Elisa Garcia, op. cit

12 "Consulta do Conselho Ultramarino ao Príncipe Regente D. João sobre o Regimento para o Novo Governo da Capitaniageral de São Pedro, Lisboa, 17 de outubro de 1807" Arquivo Histórico Ultramarino, Lisboa $(\mathrm{AHU})$. Caixas do Rio Grande do Sul, cx. 12; d. 754 Agradeço a Elisa Garcia o envio desse documento.

13 Elisa F. Garcia, op. cit.

14 M. Regina Celestino de Almeida, Metamorfoses Indígenas. Identidade e Cultura nas Aldeias Coloniais do Rio de Janeiro, Rio de Janeiro, Arquivo Nacional, 2003, pp. 79-101.

15 Idem, "Índios, Políticos e Missionários...", op. cit. 
16 Capital da colônia, desde 1763, no final do século XVIII o Rio de Janeiro já se tornara o principal centro comercial e portuário do Brasil. Desde 1751, abrigava o segundo Tribunal da Relação da colônia e a Assembléia municipal recebera, desde 1757, ofítulo de Senado da Câmara. A cidade contava, no século XVIII, com cerca de 45.000 habitantes, número que aumentaria vertiginosamente com a chegada da família real. Sobre isso, ver: Ciro Cardoso, Atlas Histórico do Rio de Janeiro, Relatório de Pesquisa do $\mathrm{CNPq}$, 1984, inédito, pp. 32-49. Marcelo Lemos, op. cit.

17 Alcir Lenharo, As Tropas da Moderação lo Abastecimento da Corte na Formação Política do Brasil-1808-18421, Rio de aneiro, Secretaria Municipal de Cultura, Turismo e Esportes, DGDI, Div. de Editoração 1993, p. 48, apud Marcelo Lemos, op. cit., p. 137. visto, a possibilidade de apresentar pessoalmente suas reivindicações ao monarca, prática que seria rapidamente aprendida pelos novos súditos indígenas estabelecidos nas aldeias tardias.

Práticas políticas diferenciadas, portanto, integravam uma mesma política indigenista que procurava assimilar"índios bravos" dos sertões e índios aliados das aldeias. Aos primeiros cabia atrair, aldear, civilizar e assimilar, enquanto aos demais, já há séculos aldeados, cabia simplesmente assimilar, misturá-los à massa populacional e extinguir as aldeias. A essas práticas, os índios responderam de formas diversas, que variavam entre colaborações, fugas, reivindicações, ameaças e ataques.

Convém atentar para o desenvolvimento socioeconômico e político da capitania que, já acentuado no Setecentos, ganharia novo impulso com a chegada da corte no início do $\mathrm{XIX}^{16}$. As conseqüências desse crescimento incidiriam sobre as populações indígenas dos sertões e das aldeias. Desde meados do Setecentos já se acentuavam no Rio de Janeiro a ocupação de terras e os conflitos em torno delas. Nas áreas de colonização antiga diminuíam as terras devolutas e aumentavam os arrendamentos e disputas sobre as terras de aldeias indígenas, enquanto no médio Vale do Paraíba a ocupação portuguesa se expandia em busca de novas terras. Achegada da corte no início do século
XIX iria acelerar consideravelmente todo esse processo. O crescimento populacional aumentou a demanda por terras e gêneros de subsistência e a política do príncipe regente incentivou a abertura de estradas que permitissem a articulação da capital com regiões no interior da colônia ${ }^{17}$. O desenvolvimento da capitania pressionava, pois, em dois sentidos: extinguir, em áreas de ocupação antiga, aldeias seculares sob a pressão de moradores e colonos interessados em suas terras e rendimentos; e ocupar novas áreas, entrando em conflito ou, de preferência, em acordo com os índios.

\section{ALDEAMENTOS TARDIOS NOS SERTÕES DOS "ÍNDIOS BRAVOS"}

Entre o final do século XVIII e o início do XIX, as margens setentrionais e meridionais do Rio Paraíba foram sendo ocupadas, através de um longo processo de negociação, conflitos e aldeamento dos índios coroados e puris, entre outros. É instigante observar que as informações sobre a selvageria desses índios contrastam com outras que afirmam sua docilidade e predisposição para se aldearem, o que aponta para a fluidez das alianças e para as mudanças de opções dos índios em suas relações de contato, conforme o
Índios numa

Fazenda, de

Johann Moritz

Rugendas

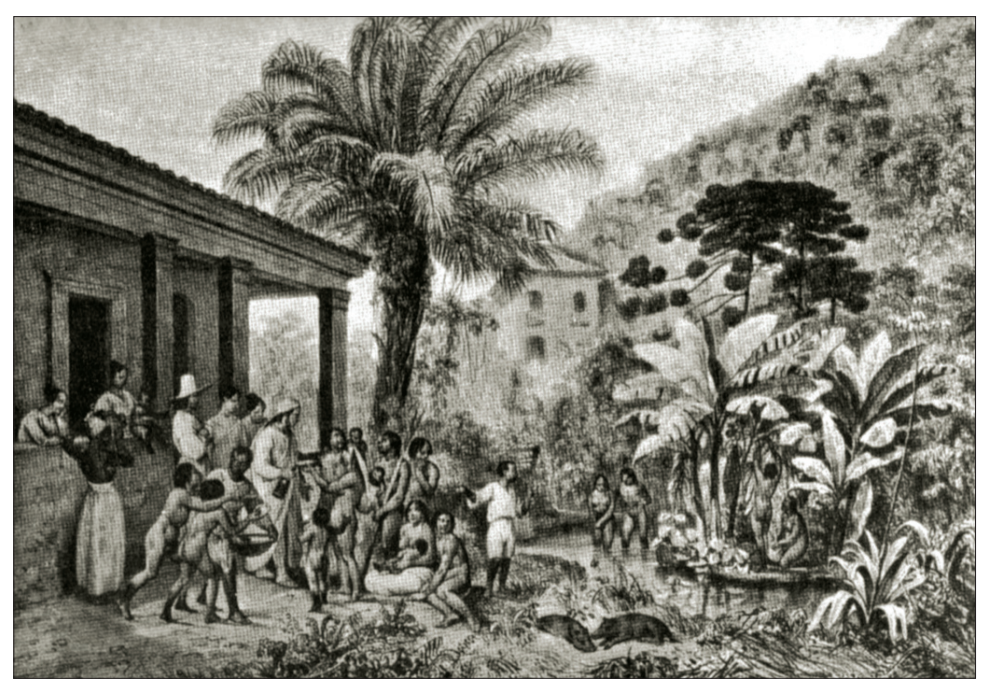

Reprodução 


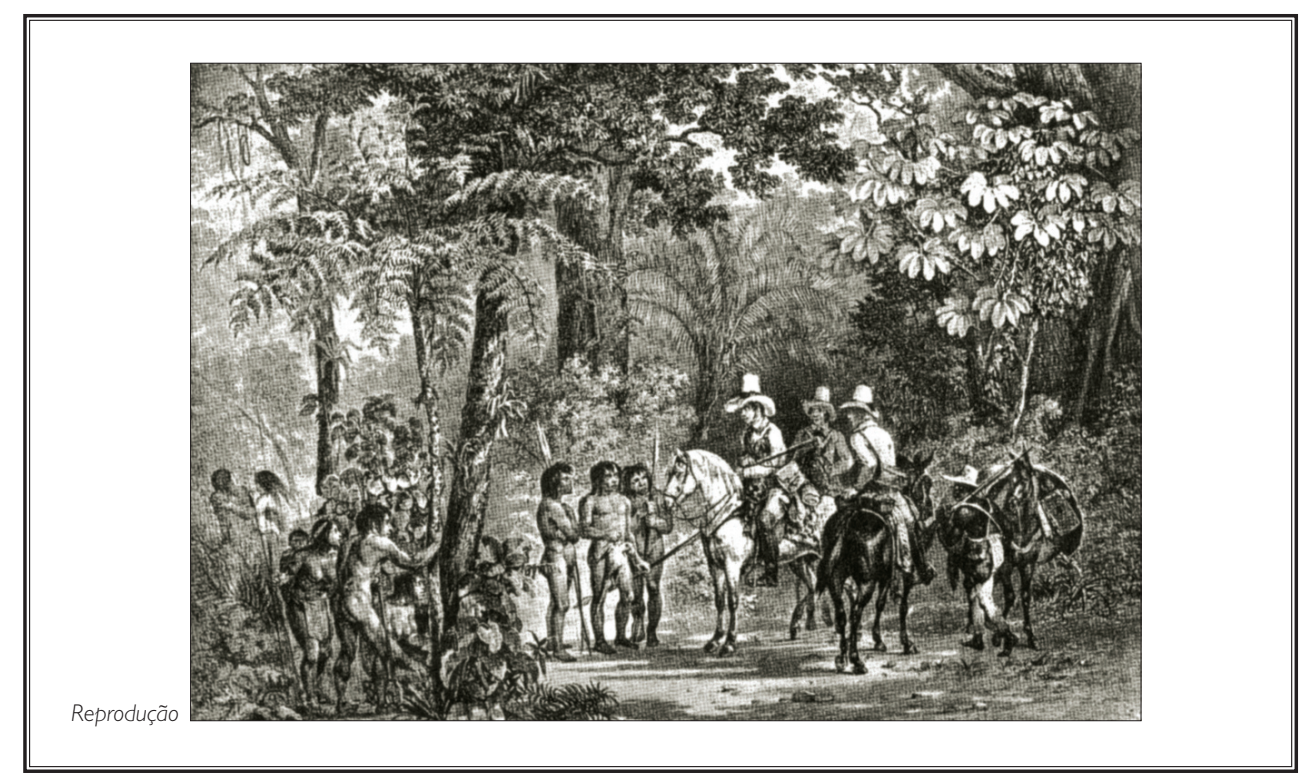

avanço da colonização. Revela também a fluidez e porosidade das fronteiras, por onde circulavam e interagiam diferentes grupos étnicos e sociais.

Embora a política de aldeamentos desse período se fizesse com objetivos e práticas bastante semelhantes aos empregados na criação das antigas aldeias para as quais, agora, pregava-se a extinção, os tempos eram outros e algumas diferenças significativas podem ser observadas. Os jesuítas tinham sido expulsos, a capitania se expandira consideravelmente levando à diminuição de terras devolutas, ao aumento de conflitos por terras em aldeias antigas e ao encolhimento dos sertões com a conseqüente diminuição das possibilidades de sobrevivência dos grupos indígenas fora dos espaços de administração portuguesa. Além disso, a legislação introduzira mudanças para acentuar as interações entre índios e não-índios. Proibidas por legislações anteriores e principalmente pelos jesuítas, que se esforçavam em vão por evitá-las, essas interações nunca deixaram de ocorrer. Tornaram-se, no entanto, muito mais frequientes a partir do Diretório, que incentivou a miscigenação e a presença de não-índios dentro das aldeias.

A nova lei adequava-se ao expansionismo crescente da capitania e aos interesses dos moradores e dos novos agentes intermediários que, substituindo os jesuítas, não tardaram em colocá-la em prática com zelo e eficiência. As idas e vindas entre sertões, aldeias e fazendas eram estimuladas e não contrariavam os interesses dos índios que circulavam livres das admoestações impostas aos seus pares no tempo dos inacianos. Somem-se a isso algumas medidas introduzidas pela Carta Régia ${ }^{18}$, sobretudo a de evitar descimentos por conta da fazenda real e incentivar particulares a realizá-los. Respaldados pela legislação, os novos mediadores usaram e abusaram dessa antiga prática que, limitada pela Coroa em tempos anteriores, tornou-se regra na criação das aldeias tardias. A ação de particulares para aldear índios e administrá-los foi admitida e incentivada, e sobre isso a aldeia de Valença é um caso exemplar.

Enquanto no norte fluminense os capuchinhos italianos tiveram papel preponderante na aproximação com os índios e no estabelecimento de novas aldeias, na região sul, destacou-se nessa tarefa o abastado fazendeiro José Rodrigues da Cruz, que, tendo sido bem-sucedido na iniciativa de aproximar-se dos coroados, foi encarregado pelo vice-rei de aldeá-los e administrá$\operatorname{los}^{19}$. Em ambas as regiões, o processo foi lento e exigiu esforço dos mediadores que, incentivados pelas autoridades, desempenharam seu papel tentando conciliar os mais diversos interesses: os seus, os do Estado, os dos moradores e os dos índios.

\section{Encontro de Índios com Viajantes Europeus, de Rugendas}

\footnotetext{
18 Patrícia Sampaio, "Entre a Tutela e a Liberdade dos Índios: Relendo a Carta Régia de 1798", in Mauro Cezar Coelho, et al. (coords.), Meandros da História. Trabalho e Poder no Grão-Pará e Maranhão - Séculos XVIII e XIX, Belém, Unamaz, 2005, p. 70.

19 Sobre o estabelecimento das aldeias nessas regiões, ver: Joaquim Norberto de Souza e Silva, op. cit., pp. 229-62. Para o norte fluminense, ver: Márcia Malheiros, "Homens de Fronteiras: Indios e Capuchinhos na Ocupação dos Sertões do Leste do Paraíba ou Goytacazes Séculos XVIII e XIX", Rio de Janeiro, UFF ltese de doutorado defendida em setembro/2007). Para os sertões de Valença, ver: Marcelo Lemos, op. cit.
} 
Quanto aos índios que ingressavam nessas novas aldeias, através dos acordos e negociações, suas expectativas não eram muito diferentes das de seus pares de períodos mais remotos: buscavam também proteção e segurança para garantir sobrevivência e terras, cada vez mais ameaçadas pelo avanço da colonização. Ao contrário dos últimos, no entanto, gozavam da liberdade de ir e vir, entre aldeias, sertões e fazendas de particulares. Variados registros informam que os índios nos sertões eram muito superiores em número aos das aldeias. Os padres e moradores mantinham com eles contatos constantes, batizando-os e procurando aldeá-los, mas também incentivandoo estabelecimento dos afilhados nas fazendas de seus padrinhos.

Sobre a chegada da corte e a influência da conjuntura das guerras napoleônicas nas relações dos sertões fluminenses, Malheiros cita instigante documento apresentado pelos capuchinhos, no qual aparecem vozes indígenas que, em 1812, ameaçavam abandonar os serviços e a lealdade ao rei português se não fossem devidamente defendidos das explorações a eles impostas por particulares. De acordo com os padres, os índios diziam:

“[...] se pois apesar de tudo, o nosso soberano não nos acudir como Pai e permitir que alguns prepotentes nos opprimam tirandonos injustamente nossas terras, e obrigandonos a uns serviços rigorosos, vede-la que, achando-nos suffocados de dezesperação, não cheguemos a dizer mal por mal, se cá vier o vosso inimigo guerrear para tomar estas terras, nós neste caso, não havemos de vos ajudar e defender, pois se vós nos opprimis e estamos gemendo debaixo de rigor, pode ser que outros não nos opprimam tanto, [...] basta que esse soberano nos procure com cuidado [...]"

Malheiros interpreta a narrativa como estratégia dos padres que, conscientes da conjuntura ameaçadora das guerras napoleônicas, buscavam fortalecer seu papel de intermediários entre os índios e o governo, sem deixar de apoiar a política de guerra imposta aos índios selvagens pelo príncipe regente, conforme relatam em suas memórias. Ainda que o discurso acima citado não tenha partido realmente dos índios, como sugere a autora, trata-se de estratégia bastante coerente com a cultura política amplamente utilizada por outros índios há mais tempo aldeados na própria capitania do Rio de Janeiro. Tinham consciência de seu papel de súditos e servidores do rei e, em troca disso, pediam proteção e garantia de suas terras. Malheiros destaca o tom de ameaça contido na citação que, segundo ela, não era freqüiente nas reivindicações dos capuchinhos. Cabe atentar, como bem ressaltou a autora, para a especial conjuntura de insegurança resultante das guerras napoleônicas que não escapava à percepção dos capuchinhos, daí o tom ameaçador. É possível pensar que talvez não escapasse também à percepção dos índios aos quais se atribui a ameaça de trocarem de soberano, caso outro lhes acenasse com maiores garantias de segurança. Afinal, no sul do continente, essa estratégia foi amplamente utilizada por outros grupos que, há mais tempo em contato com os colonizadores, conheciam bem seus códigos e sabiam utilizá-los em proveito próprio ${ }^{21}$.

\section{ALDEIA DE VALENCA: CONFLITOS E NEGOCIACÕOS}

Ao sul da capitania, nos sertões de Valença, a função de aldear outros puris e coroados coube, como visto, ao fazendeiro José Rodrigues da Cruz. Tal como os capuchinhos, o mediador agiu de forma a conciliar seus próprios interesses com os dos índios, dos fazendeiros, dos párocos e das autoridades locais e metropolitanas. Iniciou sua aproximação com os índios, em 1790, pelo menos dez anos antes de aldeá-los. De acordo com seu próprio depoimento, não eram “[...] desumanos nem intratáveis, como erradamente se supõe [...]", mas "[...] fiéis às suas promessas e agradecidos ao benefício que recebem"22. Justificava 
suas atitudes desconfiadas e vingativas, bem como roubos e assassinatos cometidos antes de seu primeiro contato com eles, pelos maus-tratos, injustiças e má-fé com que foram tratados seus chefes pelos primeiro conquistadores. Sua narrativa evidencia o cuidado em conquistar-lhes a confiança, sobretudo a do chefe. Ofereceu-lhes mantimentos e ferramentas, ordenou que seus homens baixassem as armas e apresentouos a sua família. Convenceu-os a retornar todos os anos à sua fazenda e com isso tinha grandes despesas anuais que considerava bem empregadas. Segundo ele, os índios davam prova de docilidade e gratidão, pois respeitavam tudo que lhe pertencia, como também a todos que se lhes apresentavam em seu nome. O depoimento do fazendeiro, sobretudo essa última frase, aponta para relações clientelísticas entre ele, os índios do sertão e outros moradores a ele associados, cujas boas relações com os índios, com certeza, dependiam de sua influência. Apesar das poucas referências ao trabalho dos índios nas fazendas da região, este era, com certeza, um dos principais objetivos dessa aproximação. De acordo com Lemos, os índios trocavam vários produtos com os moradores das vizinhanças, dentre os quais papagaios, macacos e cera de abelha, mas estimavam especialmente as ferramentas que lhes serviam para caça e coleta, tais como machados, foices, enxadas e facas ${ }^{23}$.

Em 1799, José Rodrigues da Cruz, em resposta ao ofício do ministro dos Negócios Ultramarinos, D. Rodrigo de Souza Coutinho, que lhe pedira informações sobre os meios para ampliar a civilização dos índios ao longo do Rio Paraíba ${ }^{24}$, manifestava sua satisfação em "[...] concorrer para o serviço da Igreja, e do Estado naquela tarefa" e solicitava

“[...] licença para ter no Rio da Parahiba huma canoa para passar do dito Rio e chegar se me parecer conveniente a hir tratar com os ditos Indios nas suas proprias Aldeyas e alojamentos, facilitando-me o Governo os Indios manços que eu pedir para me servirem de interpretes; e ficando eu responçavel pela minha conduta a respeito da administração dos ditos Indios, immediatamente a Smage, por nao ser obrigado a seguir outros planos trassados por mao alhea, q nao serao talvez tao conducentes aos fins que se propoem, e $\mathrm{q}$ tomandome todo o tempo necessario as minhas indispencaveis occupaçoes, fariao infructuosas todas as minhas diligencias, e concorreriao somente para o meu incomodo e prejuizo"25.

Evidencia-se a intenção do morador em realizar o descimento e garantir a administração particular desses índios, evitando qualquer interferência de autoridades locais. Sua carta causou grande satisfação ao ministro, que ordenou ao vice-rei o atendimento de todas as suas necessidades e ainda informou ao fazendeiro que o próprio príncipe regente havia lido sua carta ${ }^{26}$.

Apesar do forte apoio das autoridades metropolitanas ao projeto do fazendeiro, a criação da aldeia exigiria, ainda, consideráveis esforços em negociações locais, tanto com os representantes da Coroa como com as lideranças indígenas. De acordo com Lemos, a má vontade do vice-rei conde de Resende com o fazendeiro, pela desconfiança do envolvimento de sua família com movimentos revolucionários, pode ter contribuído para o atraso da criação da aldeia ${ }^{27}$. As negociações com os índios também exigiram considerável empenho por parte do mediador, segundo o qual "[...] pôde a muito custo, e sacrificando em garantia a sua mulher e filhos, resolver a que os gentios dessem quatro homens [...]"28 que o acompanharam à cidade do Rio de Janeiro para serem apresentados ao vice-rei, dando continuidade ao processo de civilizá-los. Estabelecida a aldeia em 1801, José Rodrigues da Cruz continuaria a prestar informações sobre seus contatos com os índios do sertão, visando a aumentar a aproximação com eles e a criar novas aldeias. Seus relatos evidenciam a intensa fluidez das fronteiras entre sertões, aldeias e fazendas das vizinhanças, por onde os índios circulavam.

Convém atentar para o impacto da chegada da família real sobre o ritmo e a forma de ocupação dos sertões de Valença,
23 Marcelo Lemos, op cit, p. 197

24 "Oficio do Ministro dos Negócios Ultramarinos Dom Rodrigo de Souza Coutinho de 23 de Outubro de 1798 a José Rodrigues da Cruz", in Joaquim Norberto de Souza e Silva, op. cit., p. 503.

25 "Carta de José Rodrigues da Cruz a D. Rodrigo de Souza Coutinho de 31 de Outubro de 1799", op. cit.

26 "Oficio do Ministro dos Negócios Ultramarinos Dom Rodrigo de Souza Coutinho de 7 de Marco de 1800" a José Rodrigues da Cruz, in Joaquim Norberto de Souza e Silva, op. cit., p. 504.

27 Marcelo Lemos, op. cit., p. 109

28 "Requerimento de José Rodrigues da Cruz", in loaquim Norberto de Souza e Silva, op cit, $p$. 509 
29 "Carta de losé Thomaz da Silva, de 1808", s/d, Biblioteca Nacional, Rio de Janeiro, Seção de Manuscritos, Códice 237,13, Índios de Resende apud Marcelo Lemos, op. cit. p. 133

30 Marcelo Lemos, op. cit. p. 133.

31 "Carta do Capitão Ignácio de Souza Werneck ao V.AR." ss d, Biblioteca Nacional, Rio de Janeiro, Seção de Manuscritos - Códice C 343, 6 documento no 6, apud Marcelo Lemos, op. cit., p. 134.

32 Marcelo Lemos, op. cit., p. 163.

33 "Primeiro Requerimento dos Indios da Aldeia de Nossa Senhora da Gloria de Valença", inj. Norberto de Souza e Silva op. cit., p. 518

34 "Atestado de Dom José Caetano da Silva por Mercê de Deus e da Santa Sé Apostólica Bispo do Rio de Janeiro, Capelãomor de S. M. Fidelíssima e do seu Conselho, etc., de 7 de Dezembro de 1816", in Joaquim Norberto de Souza e Silva, op. cit., p. 519. conforme assinalou Lemos. A proximidade da corte teria, segundo o autor, incentivado particulares a seguirem o exemplo de Cruz, e oferecerem seus serviços em troca da obtenção de mercês, graças e privilégios. Dentre esses, destacou-se o capitão José Thomaz da Silva, que pretendia criar, perto de sua fazenda, o aldeamento de araris, com os quais mantinha contato. Alegando dívidas contraídas pelo serviço prestado aos índios, o capitão solicitou "[...] 'formar o aldeamento preciso a aquelles Índios ficando servindo-les de director' ou então 'removelos, ou para esta corte afazerem-se outros as precisões do Estado de que são suceptíveis, ou a outro [...] lugar que for do agrado de Va. R'",29.

De acordo com Lemos, essa proposta de remoção dos índios para a corte atendia às necessidades da Armada Real e logo foram dadas ordens para que ele arregimentasse os índios necessários ao trabalho no Arsenal Real da Marinha ${ }^{30}$. Essa medida trouxe sérios prejuízos à aldeia de Valença, que foram denunciados pelo capitão de ordenanças Ignácio de Souza Werneck, em carta dirigida a Sua Alteza Real, na qual relatava a extrema violência dessa ação e rogava a restituição dos apreendidos ${ }^{31}$.

Na segunda década do Oitocentos, segundo Lemos, problemas de abastecimento da corte no Rio de Janeiro se agravaram com a seca de 1814 , ao mesmo tempo que produtos de exportação, como café, açúcar branco e couro, valorizavam-se no mercado externo, levando o príncipe regente a adotar medidas impactantes sobre a região de Valença. Incentivou-se o estabelecimento de produtores agrícolas na região, facilitando o acesso à terra e a exploração de gêneros de exportação, o que resultou no aumento da concentração fundiária e de disputas em torno das terras dos índios da aldeia de Valença ${ }^{32}$.

O processo de extinção dessa aldeia foi extremamente acelerado, e intensos conflitos sobre suas terras envolveram índios, moradores, sesmeiros e autoridades civis e eclesiásticas, entre 1816 e 1819 . José Rodrigues da Cruz, o fundador da aldeia e "protetor" dos índios, deve ter falecido entre 1803 e 1805 e não tomou parte nas contendas, finalmente resolvidas a favor dos índios com a provisão régia de 1819 de D. João VI.

Os conflitos ocorreram em torno da doação de uma sesmaria no interior da aldeia, contra a qual os índios e os moradores se insurgiram, com o apoio de autoridades civis e eclesiásticas. Em 1805, Florisbello Augusto de Macedo pediu e obteve sesmaria do sertão da aldeia de Valença, com o apoio do capitão Ignácio de Souza Werneck, que afirmou estarem devolutas as terras, e do próprio capelão da aldeia, padre Manoel Gomes Leal, que se tornara procurador do solicitante. Falecido Florisbello, sem herdeiros, Eleutério Delfim solicitou e obteve a mesma sesmaria, desencadeando as insatisfações que levaram ao conflito. Entre 1816 e1817, os índios apresentaram três requerimentos, solicitando a devolução das terras pertencentes, segundo eles, à aldeia e à matriz. Nos documentos, os índios se diziam da nação dos coroados,

"[...] miseráveis selvagens vagabundos pelos matos, sem Deus, sem rei e sem lei. Agora confiados na generosa proteção de VM vem pedir a continuação dos favores e graças [...] especialmente na concessão de uma porção de terreno para seu estabelecimento de que até agora gozavam mas de que foram esbulhados pela sesmaria que do mesmo terreno se acaba de dar a um Eleuterio Delfim pelo despacho desta corte" 33 .

Argumentavam que o terreno era para a fundação e patrimônio da igreja matriz e contaram como apoio de Dom José Caetano da Silva Coutinho, bispo do Rio de Janeiro, do novo capelão local e de Ignácio de Souza Werneck. Os depoimentos favoráveis ao pleito alegavam que o novo sesmeiro não pretendia cumprir o acordo de utilizar as terras que teriam sido doadas aos índios para "cultivarem e para se fundar uma aldeia e igreja paroquial, não só para eles, mas também para os moradores que se fossem estabelecendo no mesmo sertão"34

Essa informação de que as terras doa- 
das aos índios deviam atender também aos interesses dos moradores é coerente com a nova política de aldeamentos que visava a misturar rapidamente índios e não-índios e com as características da ocupação da região, onde os índios, como visto, viviam mais nos arredores do que na aldeia. A partir de 1815, de acordo com Lemos, o perfil demográfico da região alterou-se com a presença crescente de grandes fazendas de café e de novas vias de circulação, implementadas, como visto, pela política da corte $^{35}$. Foi nesse segundo momento que se iniciaram os conflitos, envolvendo diretamente os moradores que se insurgiram diante da possibilidade de serem dali expulsos pelo novo sesmeiro.

Diante do exposto, pode-se supor que os principais interessados no pleito poderiam ser os moradores que, com habilidade, souberam associar-se aos índios, em nome dos quais poderiam reivindicar a anulação da sesmaria de Eleutério, uma vez que a terra havia sido dada para o estabelecimento da aldeia indígena. Não é o caso, no entanto, de desconsiderar o interesse dos próprios índios nessas disputas.

Sobre isso, é instigante observar os registros do viajante Saint-Hilaire sobre seus encontros, em duas ocasiões, com grupos de coroados que se mostraram não apenas indignados com maus-tratos e invasões de suas terras, como também dispostos a reivindicar seus direitos ao rei. O primeiro encontro deu-se em novembro de 1816. De acordo com o viajante, terminada a refeição na casa de um fazendeiro,

"[...] o mais velho do grupo, que parecia o chefe, veio sentar-se aos pés do Sr. Almeida; então o mais jovem, chamado Buré, avançou para este último, e mantendo-se de pé dirigiu-lhe o discurso seguinte em mau português: 'esta terra nos pertence, e são os brancos que a povoam. Desde a morte do nosso capitão, somos escorraçados de toda a parte, e não temos mais nem lugar suficiente para poder repousar a cabeça. Dizei ao Rei que os brancos nos tratam como cães, e rogai-lhe nos dê terra para podermos construir uma aldeia"36.

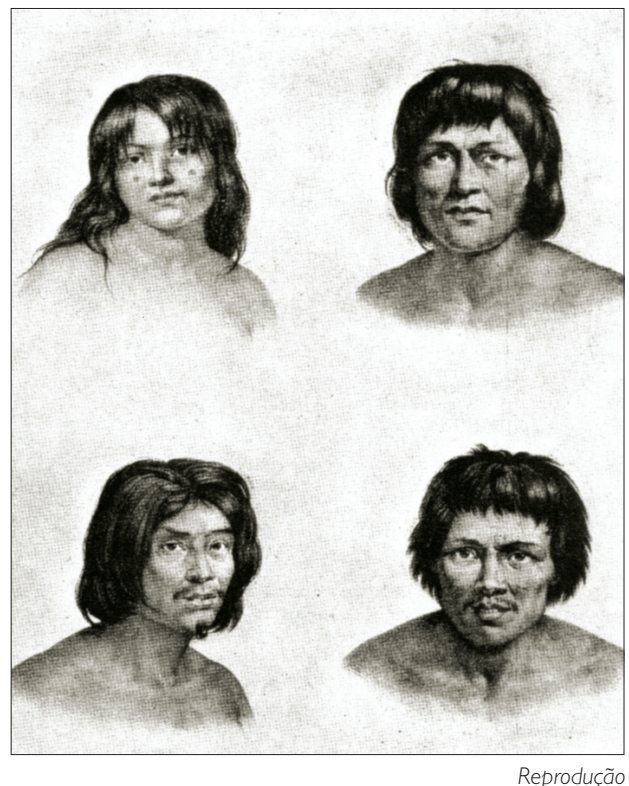

Rostos de Índios Puris, de Rugendas
No mês seguinte, Saint-Hilaire registrou o segundo encontro com um grupo que se dirigia ao Rio de Janeiro para reivindicar terras. Segundo Lemos, Buré estava entre eles e sua intenção era entregar o primeiro requerimento, acima citado, diretamente na corte. O viajante diz ter ficado

"[...] muito surpreendido de encontrar à porta da casa um grupo de doze ou quinze Coroados, mulheres e homens, entre os quais estava a maior parte dos que vira em

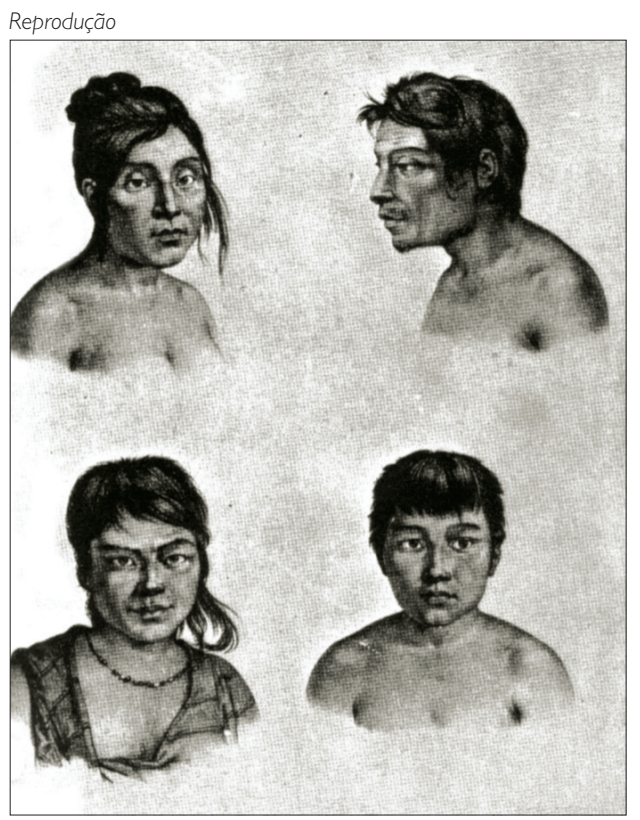

\section{Índios}

Coroados e

Coropós, de

Rugendas
35 Marcelo Lemos, op. cit., p. 126.

36 Auguste Saint-Hilaire, Viagem pelas Províncias do Rio de Janeiro e Minas Gerais, Belo Horizonte/São Paulo, Itatiaia/Ed. Universidade de São Paulo, 1974, p. 31. 
Ubá. [...]. Iam, diziam, ao Rio de Janeiro para reclamar do Rei uma légua quadrada de terras em que desejavam se estabelecer e da qual pretendiam expulsá-los"37.

Aldeados há pouco tempo, os "índios bravos" do sertão parecem ter aprendido rapidamente a cultura política do Antigo Regime, e tal como seus pares das aldeias antigas dirigiam-se ao rei para solicitar direitos, ao mesmo tempo que localmente procuravam alianças com agentes sociais que pudessem favorecê-los. Seu protetor, ao qual se referiram como o "grande capitão", havia morrido, mas buscavam outros aliados para auxiliá-los nas tentativas de amenizar suas perdas. Convém lembrar a rede de sociabilidade construída através dos batismos e das permanências nas fazendas de particulares. Ao pesquisar os registros de batismo na região, Lemos constatou que os caciques tinham como padrinhos proprietários de terras e escravos na sociedade local, o que criava uma rede de relacionamentos que favorecia o aproveitamento da mãode-obra indígena por parte dos padrinhos e o estabelecimento de agregados nas fazendas $^{38}$.

Outros requerimentos foram feitos por índios, moradores e autoridades, dando continuidade a essa contenda que, como visto, estendeu-se até 1819, quando D. João VI assinou a Provisão a favor dos índios. As associações destes últimos com os moradores devem, no entanto, ser problematizadas, pois os interesses comuns que os levaram a associar-se nessa disputa não se manteriam em litígios posteriores, que culminaram com a rápida extinção da aldeia. Depois de garantidas as terras para os índios (1819) e elevada a aldeia à categoria de vila (1826), o interesse da câmara municipal voltou-se para a incorporação daquelas terras ao seu próprio patrimônio e, a partir de então, os moradores não mais solicitariam a adesão dos índios aos seus pleitos. Ao invés disso, usariam argumentos semelhantes aos de Eleutério Delfim, afirmando que os índios não mais viviam na aldeia, o que justificaria sua extinção e a incorporação das terras ${ }^{39}$.
O desenrolar dos acontecimentos apontam, sem dúvida, para os fortes interesses dos moradores na disputa. Além disso, convém lembrar que os índios dessa região viviam mais nos sertões do que propriamente na aldeia, conforme foi atestado por depoimentos a favor de Eleutério. Dentre esses, o ouvidor da comarca, em 1818, informava não existirem no local citado os tais índios que promoviam a queixa contra o sesmeiro, queixa essa proferida, segundo ele, em favor do padre e de Francisco Dionísio, reconhecido especulador de sesmarias, interessado em retirar os índios do lugar de Tanguá, onde estavam aldeados, para colocá-los nas terras de Eleutério ${ }^{40}$.

Teriam sido os índios habilmente enganados pelos moradores? Ameu ver, esta seria uma interpretação simplista que retomaria a preconceituosa concepção de que os índios em contato com os colonizadores não agiam por interesses próprios. Embora os indícios apontem nessa direção, convém problematizá-los, considerando outros fatores já citados. Ainda que esses novos aldeados não tenham se fixado nas terras das aldeias, reconheciam seus direitos sobre elas e tinham consciência das ameaças de usurpação por não-índios. Além dos registros de SaintHilaire, outros documentos evidenciam seu empenho em defesa de seus interesses nesta e em outras regiões. De acordo com Malheiros, no norte fluminense, quando o capuchinho frei Thomaz se aproximou dos coroados, para convencer seu capitão a aceitá-los entre eles, ouviu como condição que não levasse para lá os portugueses cobiçosos de suas terras ${ }^{41}$.

Os índios de Valença igualmente manifestaram interesse em defender suas terras. Não cabe aqui aprofundar a discussão sobre este conflito, porém importa destacar a complexidade da questão e dos interesses aparentemente ambíguos e contraditórios dos diferentes agentes envolvidos. Aldeados havia apenas 15 ou 16 anos, sem saber português, esses índios agiame argumentavam, embora através de intermediários, de acordo com a cultura política do Antigo Regime e contavam com o apoio de outros agentes interessados em defender seus direitos ou 
em obter vantagens próprias, o que é mais provável, com a expulsão daquele sesmeiro. Os argumentos desenvolvidos nos requerimentos são semelhantes aos de seus pares em aldeias seculares quando se dirigiam a autoridades em busca de possíveis ganhos. Enfatizavam o fato de estarem sob a proteção de Sua Majestade, que lhes concedia favores e graça, sem esquecer que sua presença na aldeia era útil ao Estado e ao evangelho e poderia atrair novos descimentos. A importância dada à matriz era outro aspecto enfatizado nas petições dos índios. Além das terras, pediam diretor de sua confiança, demarcação das terras para evitar novas violências e garantia de que receberiam o pagamento de foros por parte daqueles que as quisessem cultivar. Apresentavam, pois, reivindicações próprias dos índios aldeados, bem parecidas com tantas outras nas mais diversas regiões, que revelam algumas de suas motivações nas alianças estabelecidas com os moradores.

A Provisão Régia de D. João VI, finalmente, encerrou o conflito, dando ganho de causa aos índios e aos moradores, de forma coerente com a política indigenista, cujo objetivo era a rápida assimilação dos índios e a extinção da aldeia. Para isso garantia que “[...] os moradores que já aí se acham com casas ou com cultura serão conservados e pagarão o foro que se the arbitrar para a câmara da vila dos mesmos índios; que será estabelecida [...]"42.

Esse processo de transformação de aldeias em vilas, passando, grosso modo, pela condição de freguesia, com o aumento cada vez maior de não-índios em seu interior, estava em curso também nas antigas aldeias da capitania desde meados do século XVIII. Ali, também não faltaram ocasiões em que índios e moradores se associaram contra um grande proprietário interessado em usurpar terras da aldeia. Foi o caso, por exemplo, de São Francisco Xavier de Itaguaí, semelhante ao da aldeia de Valença, sobretudo quanto ao desfecho, que também culminou com a criação da vila e quase imediata extinção da aldeia ${ }^{43}$. Convém considerar, no entanto, diferenças significativas quanto aos ritmos entre os pro- cessos de estabelecimento e extinção entre as antigas e as novas aldeias da capitania. Se, no primeiro caso, o movimento se fez em torno de três séculos, no segundo, deuse em cerca de três décadas. A diferença parece compreensível se levarmos em conta as mudanças na política indigenista que orientaram a criação das novas aldeias e o acentuado desenvolvimento da capitania no final do século XVIII e início do XIX que, incrementado pela chegada da família real ao Rio de Janeiro, aceleraria o processo de extinção tanto das antigas aldeias quanto das novas. Os índios, não resta dúvida, foram os grandes perdedores, mas nem por isso deixaram de agir buscando possíveis aliados entre moradores e autoridades civis e eclesiásticas.

\section{CONSIDERAÇ̃ES FINAIS}

A presença da corte no Rio de Janeiro teve, sem dúvida, efeitos diversos sobre os inúmeros povos indígenas no Brasil mas, grosso modo, afetou-as negativamente. Os mais prejudicados foram, sem dúvida, os índios considerados bárbaros, contra os quais, o príncipe regente decretou a guerra justa. Os aliados, habitantes das aldeias coloniais, acostumados à cultura política do Antigo Regime, viam o rei comojusticeiro que lhes poderia garantir os benefícios merecidos em troca dos serviços prestados. Recorreram a ele e tiveram ganhos, mas, a longo prazo, vivenciaram perdas consideráveis impulsionadas pelo crescimento da capitania e pela política assimilacionista que visava a extinguir suas aldeias e terras coletivas. Os novos índios aldeados da capitania do Rio de Janeiro, ainda considerados bravos no final do XVIII, não demoraram a aprender novas práticas culturais e políticas e a agir em moldes muito semelhantes aos de seu pares de aldeias mais antigas. Como eles, reconheciam a importância do rei e seu papel de justiceiro ao qual não deixaram de recorrer na tentativa de amenizar seus prejuízos, buscando possíveis aliados entre os agentes com os quais se relacionavam.
42 "Decreto de 26 de Marco de 1819", in Joaquim Norberto de Souza e Silva, op. cit., p. 539.

43 M. Regina Celestino de Almeida, "Política Indigenista e Etnicidade: Estratégias Indígenas no Processo de Extinção das Aldeias do Rio de Janeiro - Século XIX", in Antonio Escobar Ohmstede, Raúl Mandrini, Sara Ortelli (coords.), Sociedades en Movimiento - Los Pueblos Indigenas de America latina en el Siglo XIX, Tandil, IEHS, 2007, pp. 219-33. 